\title{
ФУНКЦІЙНА ГРАМАТИКА
}

\section{УДК 81'367.335.2}

\section{DOI: 10.18523/lcmp2522-9281.2020.6.128-145}

Анастасія Онатій

orcid id: 0000-0002-2602-1307

\section{ОСОБЛИВОСТІ ПЕРИФЕРІЙНОЇ ЗОНИ ЗАЙМЕННИКОВО-СПІВВІДНОСНИХ НЕСИМЕ ТРИЧНИХ РЕЧЕНЬ}

У статті запропоновано аналіз периферійної зони займенниково-співвідносних несиметричних речень: описано специфіку формально-граматичної організації, виявлено морфологійні транспозиційні прочеси, щчо спричиняють синсемантизацію корелята й забезпечують формування синтаксичної проєкиії, зафіксовано частотні випадки прономіналізації повнозначних частин мови в позииї співвідносного слова, досліджено семантико-синтаксичні відношення. Констатовано, щуо зміщення повнозначного слова в синтаксичну позииію корелята спричиняе посилення його дейктичної функиії й послаблення номінативної.

Ключові слова: займенниково-співвідносні речення, периферійна зона займенниково-співвідносних речень несиметричної структури, корелят, прономіналізація, транспозиція.

\section{Вступ}

Займенниково-співвідносні несиметричні речення (далі - ЗСНР) у граматичних працях XXI ст. потрактовано як сформований комплекс синтаксичних одиниць, які мають як автентичні риси, так і ознаки, що наближають їх до інших типів структур (Вихованець, 1993; Загнітко, 2001; Ломакович, 1993; Ожоган, 2017; Онатій, 2018; Слинько, Гуйванюк \& Кобилянська, 1994; Христіанінова, 2012; Шитик, 2014). Аналіз ЗСНР 
як самостійного мовного комплексу уможливлює системне наукове осмисленння цього явища, зокрема побудову класифікаційної сітки та фіксацію ядерної, напів'ядерної й периферійної зон (Онатій, 2018). У студіях із теоретичного синтаксису української мови здебільшого натрапляємо на коментарі, що стосуються ядерних несиметричних конструкцій, адже вони реалізують типові корелятивні блоки та механізм прислівно-кореляційного зв'язку (Ломакович, 1993; Ожоган, 2017; Христіанінова, 2012; Шитик, 2014). Натомість ЗСНР периферійної зони з прономіналізованими корелятами описано мало (Арделян, 2002; Шитик, 2014). У типових реалізаціях ЗСНР співвідносним словом у головній частині речення $\epsilon$ прономінатив. В. Бєлошапкова слушно зауважує, що замість нього можуть функціювати слова, які не є займенниками, але посилюють у своєму значенні дейктичний елемент (Бєлошапкова, 1989, с. 684). Активізація дейктичності і $є$ тією опорною точкою, яка уможливлює аналіз периферійної зони ЗСНР крізь призму транспозиційних процесів.

\section{Теоретичне підгрунтя}

Поява периферійної зони мовних одиниць зазвичай тісно пов'язана з транспозиційними процесами, які породжують виникнення перехідних ознак у тієї чи тієї мовної структури. У випадку ЗСНР ідеться про явища позиційної прономіналізації корелята, послаблення номінативного значення якого уможливлює формування узагальненої дейктичності й реалізацію його синтаксичної проєкції. Більшість дослідників дотримуються спільної позиції про те, що транспонований прономінатив зазнає десемантизації й розвиває вказівну функцію (Дзендзелівський, 1955, с. 16; Ожоган, 1997, с. 43; Тараненко, 2000, с. 497). Однак специфіку зазначених процесів у структурі займенниково-співвідносних речень несиметричного типу не описано. 3 огляду на це вважаємо за необхідність заповнити одну з лакун синтаксичної теорії.

Мета пропонованої статті - дослідити формально-граматичні й семантико-синтаксичні особливості периферійної зони займенниково-співвідносних речень несиметричної структури.

\section{Методи та матеріал дослідження}

Головним чинником, який впливає на появу одиниць у периферійній зоні ЗСНР, є зміщення повнозначного компонента в нетипову синтаксичну позицію корелята. У реченнях із несиметричним корелятивним блоком 
у типовій позиції співвідносного слова фіксуємо повнозначну частину мови - здебільшого прикметник, прийменниково-іменникову конструкцію або прислівник, напр.: А той, Варавва, за повстання одне, щзо сталося в місті, $i$ за вбивство, посаджений був до в'язниці, $і$ ніяк його не можна було відпустити, бо ж заслуговував на кару (Петро Улярченко); Знали інше, щчо підтверджувала совєтська влада: бандерівці покарали Крап'яка за те, щзо відмовився відчиняти їм склади зі спиртом (Василь Базів). За допомогою трансформації можемо виявити, що блоки одне щзо; інше - щуо є тотожними до класичної ядерної пари те - щзо: $A$ той, Варавва, за повстання те, щио сталося в місті, $і$ за вбивство, посаджений був до в 'язнииі, $і$ ніяк його не можна було відпустити, бо ж заслуговував на кару. Одне в реченні виконує функцію корелята, наповнюючись змістом підрядної частини (що сталося в місті) та реалізуючи об'єктну субстанційну й атрибутивну проєкції.

Утворивши пару з релятом, прикметники один, інший послаблюють конкретно-номінативне значення і посилюють дейктичне. Це наближає ïx за функцією до займенникового слова в такій позиції, уможливлює появу вказівної проєкції та заповнення ії̈ значенням підрядної частини.

У таких структурах фіксуємо дві синтаксичні проєкції, це доводить збереження прономалізованими займенниками «граматичних ознак своєї категорії (тобто класу) та особливостей своїх систем, форм, своїх парадигм» (Дзендзелівський, 1955, с. 19).

Отже, щоб проаналізувати ЗСНР периферійної зони, тобто зреалізувати поставлену мету дослідження, необхідно виявити корпус таких одиниць, простежити типові зміщення повнозначних слів у позицію корелята та зафіксувати семантико-синтаксичні відношення. Для цього доречними видаються описовий метод, а також методи зіставлення, функційного аналізу та трансформацій. Матеріалом для студіювання є твори художньої, науково-популярної, епістолярної літератури, а також публіцистичні та перекладні тексти.

\section{Прономіналізація корелята як визначальна ознака периферійної зони ЗСНР}

У системі займенниково-співвідносних несиметричних речень прономіналізація корелята реалізована як вияв тенденції повнозначних слів до розвитку дейктичності, окресленої в загальних випадках еміграційної трансформації в системі займенникових слів (Тараненко, 2000, с. 497). 
Узагальнюючи типові вияви, можна зробити висновок, що кореляти в таких ЗСНР набувають:

a) неозначеного або неозначено-узагальненого значення прономінативів якийсь, хтось, будь-який, будь-хто (корелят один);

б) неозначено-особового, узагальнено-особового, обмежувально-якісного (Вихованець, 1988, с. 164) значення (кореляти іниий, єдиний);

в) ослаблено-особового або ослаблено-предметного значення (кореляти з субсстантивами річ, справа, штука);

г) вказівно-анафоричного значення (кореляти перший, останній).

Послаблення номінативного значення слів також доводить той факт, що вони беруть участь у формуванні фразеологізованих єдностей, напр.: Людина - все одно, що иегла: обпалюючись, стає твердішою (www.zbruc.eu); Гучні заяви - не щц інше, як спосіб створити своєрідне moy (www.westnews.com.ua). Такі речення, на перший погляд, виявляють структурну модель займенниково-співвідносних несиметричних, проте рівень зрощення і лексикалізації такого блоку є значно вищим, i це не дає змоги виявити жодної синтаксичної проєкції, а отже й реалізації прислівно-кореляційного механізму. Тому такі одиниці $\epsilon$ фразеологізованими й не належать до сфери ЗСНР.

\section{Займенниково-співвідносні несиметричні речення з прикметниковим корелятом}

Хоч дослідники й зазначають, що прономіналізація прикметників належить до найбільш динамічних процесів (Дзендзелівський, 1955; Ожоган, 2016; Сич, 1984), ЗСНР із таким корелятом мають порівняно невисоку частотність у периферійній зоні. Здебільшого в утворенні корелятивної пари бере участь прикметник, якому властивий «вищий рівень абстрактності і який позначає невиразну ознаку» (Дзендзелівський, 1955, с. 18). У всіх реченнях спостерігаємо подвійну синтаксичну проєкцію корелята (набуту субстанційну та власну атрибутивну). Зафіксовано такі корелятивні блоки з прикметниковими корелятами: інший-що / коли; одне / одно - що; єдиний - що / де / куди / коли; останній-що / де / куди; перший / другий / третій - що.

Кваліфікація таких речень у науці є суперечливою як з огляду на їхнє місце в системі складнопідрядних речень, так і з огляду на особливості функціювання їхніх формально-граматичних елементів. I. Чередниченко визначає їх як призайменникові (Чередниченко, 1959, с. 112), І. Слинько 
класифікує як предметно-ототожнені зі своєрідним відтінком значення (Слинько, Гуйванюк, \& Кобилянська, 1994, с. 475), Р. Христіанінова зауважує, що кореляти реалізують у реченнях особову, предметну та подієву семантику, тому такі конструкції є складнопідрядними займенниковоспіввідносними симетричними з загальним субстанціальним значенням (Христіанінова, 2012, с. 259), Л. Шитик описує аналізовані речення як синкретичні займенниково-співвідносні субстанційно-атрибутивні, не застосовуючи для класифікації критерій симетричності (Шитик, 2014 , с. 162-163). С. Ломакович зазначає, що у структурі займенниковоспіввідносних речень співвідносні слова один, інший мають протилежну семам тотальності сему обмеженості (Ломакович, 1993, с. 27). Можемо доповнити цей перелік прикметниковими корелятами перший, останній, єдиний, які так само мають у реченнях атрибутивне обмежувальне значення: такі співвідносні слова набувають можливості реалізувати проєкцію субстанційності, яку можна кваліфікувати як невласне-субстанційність $з$ огляду на ії вторинну появу, а тому блоки з субстанційним релятом не матимуть ознак симетричності. Зазначені співвідносні слова зберігають атрибутивну проєкцію, що $є$ маркером їхнього зв'язку з попереднім класом слів. Із цих причин речення з транспонованими прикметниковими корелятами видається доречним кваліфікувати як симетричні лише в тих випадках, коли вони містять блоки з атрибутивними релятами (наприклад, який, котрий, чий). В інших випадках симетрії блоку не простежуємо, а отже речення можемо визначати як несиметричні.

ЗСНР із блоком інший - що / коли мають атрибутивну та невласнесубстанційну проєкції корелята, натомість субстанційну та адвербіальну темпоральну орієнтацію релята. Жодна з можливих комбінацій поєднання цих елементів не утворює симетричної пари. Зазвичай у реченнях фіксуємо атрибутивно-субстанційний синкретизм, напр.: Як мінімум, дві людини переказали чутки про те, щзо російський військовий катер обстріляв інший, щчо належав прикордонникам, ті відкрили у відповідь вогонь, після чого почалася паніка і було піднято в повітря вертольоти $i$ введено війська (www.bbc.com); атрибутивно-адвербіальний темпоральний синкретизм, напр.: Я люблю тебе іншу - коли ти бунтуєш, Коли гнівом під кручі клекоче Дніпро, Коли думаєш ти, коли бачиш i чуєш, I несеш від криниці вагоме відро (Василь Симоненко).

Для підсилення дейктичної функції корелята та його атрибутивної проєкції подекуди в межах блоку функціює додатковий прономінатив, 
напр.: Душа твоя щее раніше вселилася в Притулу, але то вже інша душа, зовсім інша, така інша, щцо ажс не годна вилетіти з иього прохололого вже «мерседеса» $i$ зайтися криком, відчаєм, всеочисним благанням (Віктор Баранов); Але має бути особистість, постать, людина, котра володіє інформацією з перших вуст, та інша, щзо може ставити запитання, відповіді на які зацікавлять глядачів (Тетяна Власюк).

У реченнях із парами одне / одно - щзо; єдиний - щзо; єдиний - коли;

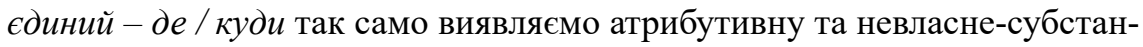
ційну проєкції корелята та субстанційну орієнтацію прономінативного релята щุo (сполучник щзо має недиференційовану проєкцію), адвербіальну темпоральну орієнтацію коли, адвербіальну локативну орієнтацію де, куди, напр.: Вона лежала така тиха, пригноблена, розтоптана і розуміла лиш одно, ще вона одинока (Михайло Коцюбинський); $A$ зараз ї̈ засмучувало одне, що не атрофувалася здатність відчувати біль, серие не ампутувалося саме по собі, а ще пам'ять... не завадила б трепанація (Наталка Шевченко); Соине, щзо є стабільним і до чого украйниі звикли, жебрацьке існування (www.gordonua.com); Сдине, коли порушувалось це питання на законній, природою продиктованій підставі, так изе при смерті батька родини або глави сім' $і$ (Тамара Давиденко); Оие є єдине, де я зможу діткнутися всіх справ, щзо Ви порушили в тім листі (Леонід Мосендз); Сдине, куди я готова тебе відпустити ненадовго, - ие до твоїх трактатів (Віолетта Лосєва). В усіх реченнях виявляємо синкретизм атрибутивно-субстанційних або атрибутивно-адвербіально-субстанційних семантико-синтаксичних відношень.

ЗСНР, формально-граматичну модель яких утворюють пари останній - щзо; останній - де, також виявляють атрибутивно-субстанційний та атрибутивно-адвербіальний локативний синкретизм, напр.: Він щзось говорив і говорив, та я не могла розібрати жодного слова, повіки злипалися, наче намазані медом, я засинала від міцного наркозу й остан$\boldsymbol{н}$, щзо змогла відчути, - це те, як він узяв мене на руки й поклав у холодне крісло (Василь Шкляр); Він невиразно пригадував той прийом після заключної сесії Об’єднаного міжнародного астрономічного конгресу в Бостоні, останній, де брали участь китайці перед другим етапом Культурної революиї (Пер. Вікторії Зенгви).

Речення із блоками перший / другий / третій - щзо, де щзо може бути й сполучником, і сполучним прономінативом, представлені найменш частотно 3-поміж групи речень із прономіналізованим прикметником, 
вони реалізують атрибутивно-субстанційний синкретизм, напр.: Той «кожен» під ту хвилю стояв біля перелазу чи біля дверей, біля вікна чи й виглядав із-за повітки; «кожен» бачив той чудний хід - ішла серединою вуличі висока, вдягнена в чорне жінка, вона несла на руках дитину, було три речі дивні у ній: перще, що ніхто ї̈ досі у вічі не бачив; друге, щчо була надто висока, та й одіж мала якусь нетутешню; а третє, щчо очі мала несусвітські (Валерій Шевчук); Перше, щчо прийшло в голову: «Дитину викрали терористи», потім з'явилася думка: «I вибухівку підкинули» (Наталя Доляк). Рідко натрапляємо також на блок перше - де: Батьки, як правило, перше, де починають иукати причини негараздів, «у вчителях та школі», вчителі, відповідно, - «у батьках та сім'ї» (Вікторія Гобунова). У таких реченнях виявлено атрибутивно-субстанційно-адвербіальний локативний синкретизм семантико-синтаксичних відношень.

Отже, у реченнях із корелятом прикметникового походження виявляємо здебільшого синкретичні семантико-синтаксичні відношення (атрибутивно-субстанційні, атрибутивно-субстанційно-адвербіальні). Таке явище спричиняє транспозиційний процес, у межах якого виявляємо поєднання послаблених ознак попереднього класу слів (забезпечення атрибутивної проєкції) та нових властивостей набутого (субстанційна проєкція).

\section{Займенниково-співвідносні несиметричні речення 3 іменниковим корелятом}

Окрім ЗСНР із прикметниковим транспонованим корелятом, до периферійної зони належать одиниці, у яких синсемантизації в позиції співвідносного слова зазнають іменники: простежуємо втрату змістової самостійності (Большова, 1960; Большова, 1970; Дзендзелівський, 1955, c. 19; Ожоган, 2016, с. 53; Тараненко, 2000, с. 497) та функційне наближення до займенників хтось, щось, дещо, те (Фінкель, \& Баженов, 1965 , с. 373). Описуючи прономіналізацію іменників (Большова, 1960; Большова, 1970; Ожоган, 1997; Ожоган, 2016), дехто з граматистів подає переліки субстантивів, які схильні до втрати конкретно-номінативного значення (завдання, ідея, історія, момент, предмет, подія, річ, тип, факт, характер тощо (Білодід, 1972; Шигуров, 2003, с. 140), щоправда, не йдеться про послаблення номінативного значення за умови зміни синтаксичної позиції в реченні. Зберігаючи зв'язок зі своїм лексико-семан- 
тичним класом, іменники забезпечують наявність субстанційних синтаксичних проєкцій та набутих адвербіальних, зокрема, темпоральних (з (від, од, до) того часу; з (від, од, до) тих пір; y (на) той час; у (на) той момент; у ту мить; на той період); локативних (y (на) тому місиі; у те місие; до (від) того місия; у той бік; у ту сторону; у изьому напрямку); причинових (з тієї причини), а також способу дії і міри (до такої міри; таким чином). У сталій прийменниково-іменниковій формі в ЗСНР виявляємо іменники час, пора, момент, мить, період, місце, бік, сторона, напрям, міра, причина, у значенні яких закладена найбільш узагальнена семантика часу, місця, міри, причини (тотожні там, mуm, mуди, тодi, так, тому).

3 огляду на компіляцію проєкцій та транспозиційні процеси, можемо припустити, що ці структури перебувають на периферії займенниковоспіввідносних несиметричних речень і не належать до сфери присубстантивно-атрибутивних чи субстантивно-означальних, як їх кваліфікують деякі науковці (Вихованець, 1993, с. 335-336; Загнітко, 2001, с. 689; Слинько, Гуйванюк, \& Кобилянська, 1994, с. 460-461). У всіх структурах простежуємо послаблення номінативної функції субстантива та посилення дейктичної, напр.: ...на той час, як ви зберетеся з дітьми в гори, у вас за спиною будуть уже кілометри прогулянок у парках, вулицями, біля проїжджих частин та інших місиь із підвищеною небезпекою (Ірена Карпа) = тоді, як ви зберетеся з дітьми в гори, у вас за спиною будуть уже кілометри прогулянок у парках, вуличями, біля проїжджих частин та інших місиь із підвищеною небезпекою.

Найбільш частотний вияв мають речення з темпоральними та локативними корелятами (з (від, од, до) того часу, з (від, од, до) тих пір, у (на) той час, y (на) той момент). Варто зазначити, що синкретизм таких конструкцій уже привертав увагу мовознавців (Ожоган, 2017, с. 214), натрапляємо на коментарі про те, що залежна частина цих речень водночас взаємодіє і з корелятом прислівним видом зв'язку, і з головною частиною речення детермінантним (Ожоган, 2017, с. 214). Л. Шитик розглядає такі речення як синкретичні атрибутивно-обставинні з уточнювальним значенням (Шитик, 2014, с. 182). Видається доречним розмежувати речення 3 різним ступенем втрати автосемантичності опорними субстантивами, напр.: Під кручею, де розмістилася його вогнева позиція, діялося щзось незвичайне (Олесь Гончар) та I прудко побігли вони до того місця, де лежало сіно пана Кошковського (Валерій Шевчук). У першому реченні 
опорний субстантив не втрачає свого зв'язку з класом, натомість у другому випадку доволі чіткою видається трансформація співвідносного блоку в ізофункційний туди - де. Лексичне значення слів бік, сторона, місце, напрямок «вичерпується в цій синтаксичній позиції вказівкою на горизонтальний просторовий орієнтир, що й забезпечує їхнє функціювання як співвідносних слів» (Арделян, 2002, с. 145).

Послідовні трансформації дають привід припускати, що в реченнях аналітичні темпоральні кореляти виконують функцію прономінативів відтодi (позначають точку відліку: з (від, од) того часу, з (від, од) тих nip), доти (позначають кінцеву часову точку: до того часу, до тих пір), тодi (власне-темпоральні: $y$ (на) той час, y (на) той момент). Релятами в таких реченнях найчастіше є коли, як. У таких структурах фіксуємо атрибутивно-адвербіальні темпоральні семантико-синтаксичні відношення: Не лічу днів. Мені не потрібні дні, й місячі, й роки. Але коли вже казати правду: то з того часу, коли козаки видали ляхам гетьмана Павлюка (Валерій Шевчук); Віта знала: ї̈ мама органічно не вміла прикидатися. 3 тих пір, коли... коли дала собі слово більше не прикидатися (Володимир Лис); На той час, як в принципі й зараз, у топах на Ютубі був розважальний контент (https://varianty.lviv.ua).

Номінативне спустошення спостерігаємо також в аналітичних блоках із субстантивами місця: у тому місиі, у той бік, у ту сторону, у изьому напрямку. Трансформуючи блоки, можемо простежити тотожність: статичний корелят у тому місиі = там, динамічні кореляти (напрямку руху

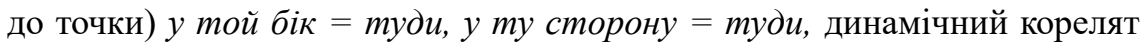
(напрямку руху від точки) у иъьому напрямку = сюди. У таких сполуках виявляємо атрибутивний прономінатив той, рідко - изей та локативні реляти де (статичний), куди (динамічний, напрямку руху до точки), звідки (динамічний, напрямку руху від точки).

Речення $з$ аналітичними локативними корелятами виражають синкретичні атрибутивно-адвербіальні локативні статичні семантико-синтаксичні відношення, напр.: Коли мундштук торкається сухих губ, він прикріплюється до губ звичайно у тому місці, де він уперше торкнувся, щьо робить досить складним знаходження «ідеальної точки» (Свген Білий); атрибутивно-адвербіальні локативні динамічно-статичні семантико-синтаксичні відношення, напр.: В його грудях стриміла Сироватчина шабля, він лежав на землі, залитий кров'ю, а гнідий бахмат 
мчав степом у той бік, де манячила постать другого втікача (Юрій Мушкетик); Натис на остроги й повернув коня у той бік, звідки почався той однотонний хід за труною (Валерій Шевчук); атрибутивно-адвербіальні локативні динамічні різноспрямованого руху: Чоловіки почули постріли та побігли у ту сторону, звідки вони лунали (https://www. pravda.com.ua).

Аналітичні атрибутивні кореляти до такої міри, у такий спосіб, які $є$ ізофункційними до настільки, так, та адвербіальний комплекс з тієї причини, який можемо прирівняти до тому, також втрачають конкретнономінативне значення. У реченнях із до такої міри здебільшого фіксуємо реляти щзо і щзоб, напр.: Тільки коли хтось із них занедужував до такої міри, щцо йому вже були чутні співи ангелів, то тоді тільки заварювали для нього грузинський чай і пекли курку (Леся Бернакевич); Маю надію, не до такої міри, щцб ти покликав варту (Олег Авраменко). У структуpax, побудованих за першою моделлю, виявляємо синкретизм атрибутивних та адвербіальних семантико-синтаксичних відношень способу дії, міри і ступеня та наслідку; у другому типі - синкретизм атрибутивних та адвербіальних способу дії, міри і ступеня та мети.

Як і прономінатив так, аналітичний комплекс у такий спосіб утворює блоки зі сполучниками щзо, щзоб, напр.: Це реалізується в такий спосіб, що правоохоронці дають можливість зв'язатись із захисником (www. zib.com.ua). У реченнях виявляємо синкретизм атрибутивних та адвербіальних способу дії та наслідку або мети (останнє залежить від орієнтації релята).

Синкретичні структури з атрибутивно-адвербіальними причини та наслідку утворює блок з тієї причини - щзо, напр.: Чуттєві образи, оповіді про конкретні подіі (наративність і симводічність) включаються в концепцію теодогічної науки з тієї причини, щчо першопринципи теодогії даються нам в Одкровенні (Андрій Баумейстер).

Отже, корелятивні комплекси з прийменником та іменником зі значенням темпоральності, локативності, способу дії та причини зазнають транспозиційних процесів, втрачаючи конкретно-номінативне значення та набуваючи посиленої дейктичної функції, що уможливлює формування прислівно-кореляційного механізму та підтверджує статус цих речень як елементів периферійної зони несиметричних займенниково-співвідносних несиметричних конструкцій. 


\section{Займенниково-співвідносні несиметричні речення з прислівниковим корелятом}

Найбільш дискусійним видається питання прономіналізації прислівників, які опиняються в позиції корелята займенниково-співвідносного речення. Усталеною $є$ позиція тих синтаксистів, які вказують на семантичне вивітрювання прислівників там, тут, десь, де-небудь, ніколи, нікуди та ін. (Вихованець, 1983; Вихованець, 1993; Городенська, 1991; Слинько, Гуйванюк, \& Кобилянська, 1994), проте думки щодо кваліфікації речень із опорними прислівниками вгорі, знизу, зверху тощо відрізняються. Такі речення кваліфікують по-різному: як складнопідрядні обставинні місця (Булаховський, 1951; Білодід, 1972), як речення місця 3 відносною підрядністю (Булаховський, 1951, с. 244), як просторовоототожнювальні (Арделян, 2002). Дехто з авторів уважає опорний прислівник корелятом із просторовим значенням (Арделян, 2002; Кващук, 1986), інші обстоюють його статус як семантично порожнього «опорного слова» (Булаховський, 1951, с. 244; Білодід, 1972) або кваліфікують речення з такими одиницями з-поміж СПР з опосередкованим зв'язком (Христіанінова, 2012; Христіанінова, 2013).

Коли прислівник із узагальненим значенням посідає місце корелята в структурі ЗСНР, він, як і проаналізовані вище повнозначні слова, зазнає послаблення номінативного значення, напр.: Іноді, коли він спить біля мене, я відчуваю, щуо є два Віктори (Любко Дереш) = Toді, коли він спить біля мене, я відчуваю, щуо є два Віктори. Тому в таких реченнях прислівники можемо вважати функційними аналогами співвідносних прономінативів, які формують корелятивний блок, а отже - утворюють займенниково-співвідносне речення нерозчленованого типу з адвербіальними локативними або темпоральними семантико-синтаксичними відношеннями. Це твердження стосується лише прислівників із найбільш загальним значенням місця або часу, які містять указівку на напрям розташування у просторі, часовий відлік тощо.

Найбільш частотними є ЗСНР із локативними адвербіальними блоками (вгорі / вгору / згори / догори / внизу / збоку / спереду / позаду / ззаду / кругом / навколо / поблизу / неподалік / набік / здалека / укінці / далеко / вперед / далі / вдалину / назад / попереду - де / куди / звідки) та темпоральними (іноді / інколи / зрідка / потім / зараз / тепер / відтепер / востаннє / вперше - коли / як). 
Локативні прислівники-кореляти, як і їхні прономінативи-аналоги, можна класифікувати на статичні (вгорі, внизу, збоку, спереду, позаду, ззаду, кругом, навколо, поблизу, неподалік, набік, укінці, далеко, далі, попереду) й динамічні напрямку руху від точки (вгору, вперед, вдалину, догори) та динамічні напрямку руху до точки (здалека, назад, згори).

У ЗСНР прислівники поблизу, неподалік, поруч можна визначити як ізофункційні до статичного локативного прономінатива тут, який вказує на наближене розміщення у просторі, або там, який вказує на віддаленість. Це засвідчують можливі трансформації: Написаний у 26 років ще достоту молодим журналістом, цей роман не так про «втрачене покоління» і поствоєнний синдром (хоча про иее також), скільки про життя як таке: коли смерть і любов ходять буквально поруч, де корида, паби і готелі є нормальними життєвими локаціями (http://www. theinsider.ua) $=$... коли смерть $і$ любов ходять буквально там, де корида, паби і готелі є нормальними життєвими локаціями.

Прислівники набік, убік, вперед, назад, вдалину, далі, далеко «вказують на такі просторові орієнтири, як горизонтальна локалізація з бічної сторони чогось, і співвідносяться з займенником туди» (Арделян, 2002, с. 146): Глипаю оком убік, куди лягла тінь, і бачу, як за мною ступає тінь мого ката (https://ar-ar.com) = Глипаю оком туди, куди лягла тінь, $і$ бачу, як за мною ступає тінь мого ката. Аналізовані пари за функцією також близькі до блоків із прономіналізованими іменниками, напр.: набік у той бік, у ту сторону тощо.

У ЗСНР із адвербіальними локативними прислівниками послідовно реалізовано адвербіальні локативні статичні семантико-синтаксичні відношення, напр.: ... кар, кар, карр! - загойдалися віти високо вгорі, де кудись зникла стеля: накладка вийшла, встигла зрозуміти Мілена (Оксана Забужко); динамічно-статичні, напр.: Bci, сперши дуx, дивляться угору, де в блакиті неба ширяв степовий хижак (Адріан Кащенко). У всіх реченнях спостерігаємо контактне розташування прислівника й релята, що посилює їхню взаємодію.

Темпоральними прислівниками, які мають тенденцію втрачати повнозначну семантику, є такі: іноді, інколи, зрідка, потім, зараз, тепер, відтепер, востаннє, вперше. Вони, як і їхні прономінативні аналоги, виражають власне-час (іноді, інколи, зрідка, потім, зараз, тепер, востаннє, вперше) або відліковість (відтепер). 
У підрядній частині речень із темпоральними корелятами здебільшого функціюють реляти коли, як. У таких структурах фіксуємо адвербіальні темпоральні семантико-синтаксичні відношення: Iноді, коли я залишалася сама на горищі, дивлячись у низьке осінне небо, думала, що чекає на мене за цими стінами, чого хочу, яка я? (Олена Печорна); Хворий щасливий, коли стає здоровим, а потім, коли звикне, знову нарікає (Дара Корній); Справа в тому, щзо востаннє, коли я бачив Мішель, ми багато говорили про нього (Пер. Ганни Литвиненко).

Так само, як і в реченнях із прикметниковими корелятами, фіксуємо випадки подвійного співвідносного слова, у якому додатковий прономінатив посилює дейктичну функцію корелята, напр.: Крім того, - він подививсь кудись угору, де буяла й гоготіла пожежа, - мені треба поховати й ворогів моїх (Віктор Савченко); Але в «Лондоні» годі й думати спинитись: "Бруднющі кам'яні східиі крутяться кудись угору, де смердить якимись бридкими випарами, карболкою й на стінах чатують блощииіџ (Леонід Бойко).

Отже, вважаємо за доцільне розглядати речення з корелятом-прислівником із найбільш узагальненою семантикою, тотожною 3 прономінативами там, mym, myди, звідти, тод $i$, який має контактну позицію щодо релята й набуває в ЗСНР дейктичної функції корелята, як периферійний вияв займенниково-співвідносних несиметричних структур.

\section{Висновки}

Підсумовуючи, можемо зробити висновок, що на периферії займенниково-співвідносних несиметричних речень перебувають конструкції, у яких виявляємо транспозицію повнозначних частин мови. Ключовим чинником цього процесу є синтаксичний - зміна позиції й набування повнозначним компонентом функції корелятивного слова, що передбачає послаблення номінативного й посилення дейктичного значень. До сфери таких речень належать одиниці з прономіналізованими прикметниками, іменниками та прислівниками з найбільш узагальненою семантикою.

У позиції співвідносного слова корелятивного блоку ЗСНР фіксуємо прикметники з високим рівнем абстрактності, які називають невиразну ознаку: інший - щоо / коли; одне / одно - щуо; єдиний - щуо / де / куди / коли; останній-щ̧о / де / куди; перший / другий / третій-щ̧о. У таких 
реченнях виявляємо здебільшого синкретичні семантико-синтаксичні відношення (атрибутивно-субстанційні, атрибутивно-субстанційно-адвербіальні).

Іменники 3 найбільш узагальненою семантикою часу, місця, міри, причини утворюють сталі прийменниково-іменникові сполуки в корелятивних блоках 3СНР: $з$ (від, од, до) того часу; з (від, од, до) тих пір; y (на) той час; $y$ (на) той момент; у ту мить; на той період; $у$ (на) тому місиі; у те місие; до (від) того місия; у той бік; у ту сторону; у цъьому напрямку; з тієї причини; до такої міри; таким чином. У таких реченнях фіксуємо синкретичні атрибутивно-адвербіальні темпоральні та локативні семантико-синтаксичні відношення (статичні, динамічно-статичні та динамічні), а також атрибутивно-адвербіальні відношення способу дії, наслідку та мети.

Найбільш частотними в ЗСНР із прислівником у позиції корелята $\epsilon$ локативні адвербіальні (вгорі / вгору / згори / догори / внизу / збоку / спереду / позаду / ззаду / кругом / навколо / поблизу / неподалік / набік / здалека / укінці / далеко / вперед / далі / вдалину / назад / попереду - де / куди / звідки) та темпоральні (іноді / інколи / зрідка / потім / зараз / тепер / відтепер / востаннє / вперше - коли / як) блоки. У таких реченнях виявляємо адвербіальні локативні (статичні, динамічні) та темпоральні семантико-синтаксичні відношення.

\section{Список використаної літератури}

Арделян, М. В. (2002). Складнопідрядні просторово-ототожнювальні речення в сучасній українській мові. Харків.

Бєлошапкова, В. А. (1989). Современный русский язык. Москва: Высшая школа.

Білодід, І. К. (Ред.). (1972). Сучасна українська літературна мова. Синтаксис. Київ: Наукова думка.

Большова, Ю. В. (1960). К вопросу о прономинализации в современном русском языке. Вопросы русского языкознания, 4, 50-59.

Большова, Ю. В. (1970). Развитие местоименно-неопределенных значений в прономинализированных прилагательных в современном русском языке. Вісник Львівського національного університету, 7, 81-85.

Булаховський, Л. А. (1951). Курс сучасної української літературної мови, Т. 2. Синтаксис. Київ: Радянська школа.

Вихованець, І. Р. (1988). Частини мови в семантико-синтаксичному аспекті. Київ: Наукова думка.

Вихованець, І. Р. (1993). Граматика украӥнської мови. Синтаксис. Київ: Либідь.

Вихованець, І. Р., Городенська, К. Г., \& Русанівський, В. М. (1983). Семантико-синтаксична структура речення. Київ: Наукова думка. 
Городенська, К. Г. (1991). Деривація синтаксичних одиниць. Київ: Наукова думка.

Дзендзелівський, Й. О. (1955). Прономіналізація в українській мові. Украӥнська мова в школі, 1, $14-20$.

Загнітко, А. П. (2001). Теоретична граматика украӥнської мови. Синтаксис. Донецьк: ДонНУ.

Кващук, А. Г. (1986). Синтаксис складного речення. Київ: Радянська школа.

Ломакович, С. В. (1993). Займенниково-співвідносні речення в сучасній украйнській мові. Тернопіль.

Ожоган, В. М. (1997). Займенникові слова у граматичній структурі сучасної украӥнської мови. Київ: НАН України, Інститут української мови.

Ожоган, В. М. (2016). Транспозиція незайменникових слів до займенникових. Лінгвістика, $X X V$, $16-21$.

Ожоган, В. М. (2017). Синкретизм складнопідрядних речень займенниково-співвідносного типу симетричної структури. Мова: класичне -модерне - постмодерне, 3, 209-218.

Онатій, А. В. (2018). Синтаксична організачія складнопідрядних займенниково-співвідносних речень несиметричної структури. Вінниця.

Сич, В. Ф. (1984). Перехід у займенники слів інших частин мови. Украӥнська мова й література в иколі, 10, 33-35.

Слинько, І. І., Гуйванюк, Н. В., \& Кобилянська, М. Ф. (1994). Синтаксис сучасної української мови: проблемні питання. Київ: Вища школа.

Тараненко, О. О. (2000). Прономіналізація. В В. Русанівськвий, О. Тараненко, О. Зяблюк та ін. (Ред.), Українська мова: енциклопедія (с. 496-497). Київ: «Укр. енцикл».

Фінкель, А. М., \& Баженов, Н. М. (1965). Курс современного русского литературного языка. Київ: Радянська школа.

Христіанінова, Р. О. (2012). Складнопідрядні речення в сучасній украӥнській літературній мові. Київ: Інститут української мови, Видавничий дім Дмитра Бураго.

Христіанінова, Р. О. (2013). Формально-граматична і семантико-синтаксична типологія складнопідрядних речень. Київ.

Чередниченко, І. Г. (1959). Складнопідрядні речення в сучасній украӥнській мові. Чернівці: ЧДУ.

Шигуров, В. В. (2003). Прономинализация как тип ступенчатой транспозиции словоформ в системе частей речи. Саранск: Красного октября.

Шитик, Л. В. (2014). Синхронна перехідність синтаксичних одиниць в украӥнській літературній мові. Черкаси: видавець Чабаненко Ю. А.

\section{References}

Ardelyan, M. (2002). Skladnopidryadni prostorovo-ototozhnyuvalni rechennya v suchasniy ukrayinskiy movi [The complex locative-identifying sentence in the Modern Ukrainian language]. Kharkiv [in Ukrainian].

Beloshapkova, V. (1989). Sovremennyj russkij yazyk [The Modern Russian language]. Moskva: Vysshaja shkola [in Russian].

Bilodid, I. K. (Ed.). (1972). Suchasna ukrainska literaturna mova. Syntaksys [The Modern Ukrainian literary language. Syntax]. Kyiv: Naukova dumka [in Ukrainian].

Bolshova, Ju. (1960). K voprosu o pronominalizacii v sovremennom russkom jazyke [About pronominalisation in Modern Russian language]. Voprosy russkogo jazykoznanija, 4, 50-59 [in Russian].

Bolshova, Ju. (1970). Razvitie mestoimenno-neopredelennyh znachenij v pronominalizirovannyh prilagatelnyh $\mathrm{v}$ sovremennom russkom jazyke [The development of pronoun-indefinite meanings 
in pronominalized adjectives of the Modern Russian language]. Visnik Lvivskogo nacionalnogo universitetu, 7, 81-85 [in Russian].

Bulakhovskyy, L. (1951). Kurs suchasnoyi ukrayinskoyi literaturnoyi movy, T. 2. Syntaksys [The course of Modern Ukrainian literary language]. Kyiv: Radyanska shkola [in Ukrainian].

Cherednychenko, I. (1959). Skladnopidryadni rechennya v suchasniy ukrayinskiy movi [Complex sentences in modern Ukrainian literary language]. Chernivtsi: ChDU [in Ukrainian].

Dzendzelivskyy, Y. (1955). Pronominalizatsiya v ukrayinskiy movi [Pronominalization in the Ukrainian language]. Ukrayinska mova v shkoli, 1, 14-20 [in Ukrainian].

Finkel, A., \& Bazhenov, N. (1965). Kurs sovremennogo russkogo literaturnogo jazyka [The course of Modern Russian literary language]. Kyiv: Radjanska shkola [in Russian].

Horodenska, K. (1991). Deryvatsiya syntaksychnykh odynyts [Derivation of syntactic units]. Kyiv: Naukova dumka [in Ukrainian].

Khrystianinova, R. (2012). Skladnopidriadni rechennia v suchasnii ukrainskii literaturnii movi [Complex sentences in modern Ukrainian literary language]. Kyiv: Vydavnychyi dim Dmytra Buraho [in Ukrainian].

Khrystianinova, R. O. (2013). Formalno-hramatychna i semantyko-syntaksychna typolohiia skladnopidriadnykh rechen. Kyiv [in Ukrainian].

Kvashchyk, A. (1986). Syntaksys skladnoho rechennya [Syntax of the Complex sentence]. Kyiv: Radyanska shkola [in Ukrainian].

Lomakovych, S. (1993). Zaymennykovo-spivvidnosni rechennya v suchasniy ukrayinskiy movi [Pronoun-corelated sentences in the Modern Ukrainian language]. Ternopil [in Ukrainian].

Onatii, A. (2018). Syntaksychna orhanizatsiya skladnopidryadnykh zaymennykovo-spivvidnosnykh rechen nesymetrychnoyi struktury [Syntactic Organization of Pronoun-correlated Sentences with Non-symmetrical Structure]. Vinnytsya [in Ukrainian].

Ozhohan, V. (1997). Zaymennykovi slova u hramatychniy strukturi suchasnoyi ukrayinskoyi movy [Pronominal words in the grammatical structure of the Modern Ukrainian language]. Kyiv: NAN Ukrayiny, Instytut ukrayins'koyi movy [in Ukrainian].

Ozhohan, V. (2016). Transpozytsiia nezaimennykovykh sliv do zaimennykovykh [Transposition of non-pronominal words into pronominal ones]. Linhvistyka, XXV, 16-21 [in Ukrainian].

Ozhohan, V. (2017). Synkretyzm skladnopidryadnykh rechen' zaymennykovo-spivvidnosnoho typu symetrychnoyi struktury [Syncretism of complex pronoun-correlated sentences with symmertical structure]. Mova: klasychne-moderne-postmoderne, 3, 209-218 [in Ukrainian].

Shigurov, V. (2003). Pronominalizacija kak tip stupenchatoj transpozicii slovoform v sisteme chastej rechi [Pronominalization as a type of stepwise transposition of word forms in the system of parts of speech]. Saransk: Krasnogo oktjabrja [in Russian].

Shytyk, L. (2014). Synkhronna perekhidnist syntaksychnykh odynyts v ukrayinskiy literaturniy movi [Synchronic transitivity of syntactic units in the Ukrainian standard language]. Cherkasy: Vydavets' Chabanenko Yu. A. [in Ukrainian].

Slynko, I., Huivaniuk, N., \& Kobylianska, M. (1994). Syntaksys suchasnoi ukrainskoi movy: Problemni pytannia [Syntax of the modern Ukrainian language. Discussion Issues]. Kyiv: Vyshcha shkola [in Ukrainian].

Sych, V. (1984). Perekhid u zaymennyky sliv inshykh chastyn movy [Other parts of speech transition into pronouns]. Ukrayinska mova y literatura v shkoli, 10, 33-35 [in Ukrainian].

Taranenko, O. (2000). Pronominalizatsiya [Pronominalization]. In V. Rusanivskvyy, V. Taranenko, O. Zyablyuk et al. (Eds.), Ukrayinska mova: entsyklopediya (pp. 496-497). Kyiv: "Ukr. entsykl." [in Ukrainian]. 
Vykhovanets, I. (1988). Chastyny movy vsemantyko-hramatychnomu aspekti [Part of Speech in Semantic and Grammatical Aspect]. Kyiv: Naukova dumka [in Ukrainian].

Vykhovanets, I. (1993). Hramatyka ukrainskoi movy. Syntaksys [Grammar of the Ukrainian Language Syntax]. Kyiv: Lybid [in Ukrainian].

Vykhovanets, I., Horodenska, K., \& Rusanivskyy, V. (1983). Semantyko-syntaksychna struktura rechennya [Semantic and grammatical sentence structure]. Kyiv: Naukova dumka [in Ukrainian].

Zahnitko, A. (2001). Teoretychna hramatyka ukrainskoi movy. Syntaksys [Theoretical grammar of the Ukrainian language. Syntax]. Donetsk: DonNU [in Ukrainian].

Abstract

Anastasiia Onatii

\section{SPECIFIC FEATURES OF NON-CORE PERIPHERAL AREA IN PRONOUN-CORRELATED ASYMMETRICAL SENTENCES}

Background. The article focuses on defining the non-core peripheral functional area of pronoun-correlated sentence with non-symmetrical structure. In sentences where the position of the correlative word is taken by a lexical part of speech there is frequent emigrational transformation of pronominal words. Such constructions are realised by means of correlative blocks with pronominatives of adverbial, adjectival, noun semantics. Besides the main word, sentences with noun have pronoun re, which does not have pronounced meaning and forms a variety of pairings with prepositions, based on which it indirectly creates a syntactic projection ensuring the formation of mostly syncretic semantic-syntactic relations.

The purpose of this paper is to analyse formal-grammatical and semantic-syntactic structure of non-core functional peripheral area of pronoun-correlated sentence with non-symmetrical structure.

Methods. The research made use of descriptive and comparative methods. Additionally, the elements of transformative method and functional analysis were applied.

Results. The findings of this study reveal that the non-symmetrical type of such sentences is represented by three models: the first is formed through the combination of an adjectival word with a relative word with substantive semantics; the second is formed by an adverbial locative correlative word of direction and a non-symmetrical relative word, usually locative but with different semantics; 
the third contains a synsemantic noun in the main clause. Apart from pronominal words, the position of the correlative word can be taken by word forms with weakened nominative meaning, e.g. у такий спосіб, до того часу, до такої міри. Sentences with such constructions demonstrate transpositional processes within pronoun-correlated sentences with non-symmetrical structure.

Discussion. The research is aimed at filling one of the gaps in the general theory of the complex sentence and completes the extant classification of pronoun-correlated sentences. This study enriches that non-core functional area of pronoun-correlated sentence with non-symmetrical structure consists of the units that represent one of the independent parts of speech in the position of correlative world. This position increases diactic role of noun, adjective or adverb and weakens their nominative significance.

Keywords: complex pronoun-correlated sentence, non-core functional area of pronoun-correlated sentence, relative word, correlative word, pronominalisation, transposition.

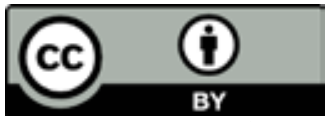

Матеріал надійшов 03.09.2020

Creative Commons Attribution 4.0 International License (CC BY 4.0) 